Democratisation in the Maghreb 



\title{
DEMOCRATISATION IN THE MAGHREB
}

\author{
$\infty$ \\ J. N. C. Hill
}

EDINBURGH

University Press 
Edinburgh University Press is one of the leading university presses in the UK. We publish academic books and journals in our selected subject areas across the humanities and social sciences, combining cutting-edge scholarship with high editorial and production values to produce academic works of lasting importance. For more information visit our website: edinburghuniversitypress.com

(C) J. N. C. Hill, 2016

Edinburgh University Press Ltd

The Tun - Holyrood Road

12 (2f) Jackson's Entry

Edinburgh EH8 8PJ

Typeset in 11/13 JaghbUni Regular by

Servis Filmsetting Ltd, Stockport, Cheshire

and printed and bound in Great Britain by

CPI Group (UK) Ltd, Croydon CR0 4YY

A CIP record for this book is available from the British Library

ISBN 9781474408974 (hardback)

ISBN 9781474408981 (webready PDF)

ISBN 9781474408998 (epub)

The right of J. N. C. Hill to be identified as author of this work has been asserted in accordance with the Copyright, Designs and Patents Act 1988 and the Copyright and Related Rights Regulations 2003 (SI No. 2498). 